\title{
(JIPD)
}

Jurnal Inovasi Pendidikan Dasar

Vol. 4, No. 1, Bulan Januari Tahun 2020, Hal. 6-11

E-ISSN: 2598-408X, P-ISSN: 2541-0202

http://unikastpaulus.ac.id/jurnal/index.php/jipd

\section{PENERAPAN MODEL PEMBELAJARAN KOOPERATIF TIPE JIGSAW TEMA PRISTIWA DALAM KEHIDUPAN PADA SISWA KELAS V SDN GADUNG DRIYOREJO GRESIK}

\author{
Siti Rosita Vinilia ${ }^{1}$ \\ Pogram Studi Pendidikan Guru Sekolah Dasar \\ Universitas Wijaya Kusuma Surabaya \\ Email: sitirositavinilia@gmail.com \\ Desi Eka Pratiwi ${ }^{2}$ \\ Pogram Studi Pendidikan Guru Sekolah Dasar \\ Universitas Wijaya Kusuma Surabaya \\ Email: pratiwidesi27@gmail.com
}

Diterima: 11 Januari 2020, Direvisi: 15 Januari 2020, Diterbitkan: 31 Januari 2020

\begin{abstract}
This research aims to implement jigsaw learning models in primary school. This research is qualitative descriptive, The data of this research were collected using observation, test, and questionnaire. Based on research result, obtained data as follows: (1) teacher activity data get a percentage 82,3\% with the conversion of grades $81 \%-100 \%$ included in the excellent category. (2) student activity data get a percentage of $89,6 \%$ with the conversion of grades $81 \%-100 \%$ included in the category of very active. (4) the result of the questionnaire responses of students get a percentage of agree for $62 \%$ and disagree for $36 \%$, student response data shows an increase. (4) classical learning outcomes get a percentage 87,24\%, there are only 3 out of 29 students whose grades are below 75 , so learning outcomes are included in the complete category.
\end{abstract}

Keywords: cooperative learning, jigsaw, primary school

Abstrak: Penelitian ini bertujuan untuk menerapkan model pembelajaran jigsaw di sekolah dasar. Jenis penelitian ini adalah deskriptif kualitatif, teknik pengumpulan data menggunakan observasi, tes dan angket. Berdassarkan hasil penelitian diperoleh data sebagai berikut. (1) data aktivitas guru mendapatkan presentase $82,3 \%$ dengan konversi nilai $81 \%-100 \%$ termasuk dalam kategori sangat baik. (2) data aktivitas siswa mendapatkan presentase sebesar 89,6\% dengan konversi nilai 81\%-100\% termasuk dalam kategori sangat aktif. (3) hasil Kuesioner respon siswa mendapatkan presentase sangat setuju sebesar $62 \%$ dan tidak setuju sebesar $36 \%$ data respon siswa menunjukkan adanya peningkatan. (4) hasil belajar secara klasikal terpenuhi sebesar $87,24 \%$, hanya terdapat 3 dari 29 siswayang nilainya dibawah 75 Sehingga termasuk dalam kategori tuntas.

Kata Kunci: model pembelajaran kooperatif, jigsaw, sekolah dasar

\section{PENDAHULUAN}

Pendidikan merupakan sebuah sistem yang terbangun dalam beberapa komponen, yaitu pendidik, peserta didik, tujuan pendidikan, alat pendidikan, dan lingkungan pendidikan. Pendidikan merupakan suatu proses yang mencakup tiga dimensi, individu, masyarakat atau komunitas nasional dari individu tersebut dan seluruh kandungan realitas baik material maupun spiritual (Nurkholis 2013:24). Semua komponen yang membangun sistem pendidikan saling berhubungan, saling tergantung, dan saling menentukan satu sama lain. Setiap komponen memiliki fungsi masing-masing dalam rangka mencapai tujuan pendidikan. oleh karena itu, suatu proses aktivitas yang memiliki maksud dan tujuan tertentu yang diarahkan untuk mengembangkan potensi yang dimiliki manusia ataupun sebagai masyarakat dengan sepenuhnya. Sebab masyarakat dalam penyelenggaraan 
pendidikan, kadang tidak menyadari bahwa pendidikan terbangun dalam sebuah sistem, sehingga dalam melaksanakan penilaian terhadap aktivitas dan hasil pendidikan, mereka hanya melemparkan tanggung jawab keberhasilan dan kegagalan pendidikan kepada guru. Karena itu guru bertugas untuk mewujudkan pendidikan yang adil dan merata, Serta mengembangkan pembelajaran yang efektif dan efisien. Dalam memelihara dan memberi latihan diperlukan adanya ajaran, tuntunan dan pimpinan mengenai akhlak, kecerdasaan, pikiran peserta didik maka perlu peran seorang guru.

Belajar merupakan suatu proses yang ditandai dengan perubahan pada diri seseorang. Perubahan sebagai hasil dari proses belajar dapat ditunjukan dalam berbagai bentuk seperti perubahan pengetahuan, pemahaman, sikap, dan tingkah laku, keterampilan, kecakapan, kebiasaan, serta perubahan aspek-aspek lain yang ada pada pada individu belajar. Surya dalam Komara (2014:2) belajar sebagai suatu proses usaha yang dilakukan individu untuk memeroleh suatu perubahan perilaku yang baru secara keseluruhan sebagai hasil pengalaman individu itu sendiri dalam berinteraksi dengan lingkungan.Belajar tuntas merupakan tujuan proses belajar mengajar secara idel agar bahan yang dipelajari dikuasai sepenuhnya oleh murid. (Pratiwi, 2017).

IPA merupakan cabang pengetahuan yang berawal dari fenomena alam yang diperoleh dari hasil pemikiran yang dilakukan dengan keterampilan bereksperimen. Dengan demikian, pada hakikatnya IPA merupakan ilmu pengetahuan alam tentang gejala alam yang dituangkan berupa fakta, konsep, prinsip, dan yang teruji kebenarannya dan melalui suatu rangkain kegiatan. Menurut Julianto dkk (2017:35) IPA adalah sekumpulan pengetahuan tentang objek dan fenomena alam. Objek dan fenomena alam tersebut diperoleh dari hasil pemikiran, dan penemuan para ilmuwan yang ahli dalam bereksperimen dengan metode ilmiah. Secara umum IPA merupakan suatu mata pelajaran dimana didalamnya terdapat pengetahuan, observasi, dan eksperimen.

Model pembelajaran kooperatif merupakan salah satu model pembelajaran yang membagi siswa kedalam kelompok kecil yang memiliki tingkat kemampuan berbeda. Dalam menyelesaikan tugas kelompok, setiap anggota saling bekerja sama dan membantu untuk memahami suatu bahan pembelajaran. Karena itu, Pembelajaran kooperatif ini merupakan salah satu konsep yang lebih luas meliputi semua jenis kerja kelompok termasuk bentuk-bentuk yang lebih dipimpin oleh guru. Para siswa akan duduk bersama dalam kelompok yang beranggotakan empat orang untuk menguasai materi yang disampaikan guru dan siswa diminta untuk bekerja sama saling membantu dan bertanggung jawab dalam kegiatan belajar. Menurut Shoimin (2016:45) pembelajaran kooperatif adalah kegiatan pembelajaran dengan cara berkelompok untuk bekerja sama saling membantu mengonstruksi konsep dan menyelesaikan persoalan.

Model pembelajaran di SD ada begitu banyak namun tidak semua model pembelajaran yang cocok diterapkan pada mata pelajaran tertentu. Sehingga dalam memilih model pembelajaran harus disesuaikan dengan karakteristik mata pelajaran yang akan diajarkan salah satunya mata pelajaran IPA. Dalam model Jigsawpada proses pelaksanaan pembelajaran menitikberatkan pada kemampuan berfikir dalam memecahkan suatu masalah. Dengan menggunakan model pembelajaran ini siswa akan lebih aktif berpartisipasi dalam pembelajaran karena akan terjadi intraksi antara siswa maupun siswa dengan guru dan pencapaian tujuan pembelajaran akan lebih aktif dan hasil pembelajaran akan lebih maksimal.

Sudrajat (2008:1) model pembelajaran Jigsaw sebagai sebuah tipe model pembelajaran yang dilakukan secara berkelompok, dalam 1 kelompok terdiri dari beberapa siswa yang bertanggung jawab untuk menguasai bagian dari materi ajar dan selanjutnya harus mengajarkan materi yang telah dikuasai kepada teman satu kelompoknya. Dalam proses mengajarkan akan terjadi diskusi dan ditemukan beberapa perbedaan pendapat yang dikarenakan oleh perbedaan pemahaman atas materi yang dipelajari oleh masing-masing siswa. Oleh karena itu, setiap kali oleh seorang siswa mengajarkan sesuatu kepada yang lainnya dan apa yang telah dipelajarinya, akan terjadi timbal balik dari pihak pembelajar berdasarkan materi yang dipelajari.Menurut Zini (2008:56) model pembelajaranJigsaw merupakan strategi yang menarik untuk di gunakan jika materi yang akan di pelajari dapat dibagi menjadi beberapa bagian dan materi tersebut tidak mengharuskan urutan penyampaian. Kelebihan strategi ini adalah dapat melibatkan seluruh peserta didik dalam belajar sekaligus mengajarkan kepada orang lain.

Berdasarkan nilai harian siswa pada semester II tahun ajaran 2018/2019 di kelas V 
SDN Gadung Driyorejomenunjukkan bahwa nilai perolehan siswa pada pelajaran tersebut sangat rendah dibandingkan pelajaran lainya. Dari 29 siswa hasil observasi awal di lapangan menunjukkan bahwa kemampuan siswa kelas V SDN Gadung Driyorejo Gresik dalam memahami materi mata pelajaran IPA masih kurang. Hal tersebut dapat dilihat dari nilai pencapaian siswa yang masih belum mencapai Kriteria Ketuntasan Minimal (KKM) yang ditetapkan sekolah yaitu $\geq 75$. Rendahnya mata pelajaran IPA materi Perubahan Wujud Benda nilai siswa kelas V SDN Gadung Driyorejo Gresik yang mungkin disebabkan metode yang digunakan Guru Sekolah Dasar dalam pembelajaran masih kurang tepat.

\section{METODE PENELITIAN}

Jenis Penelitian yang digunakan dalam penelitian ini adalah deskriptif kualitatif untuk mendeskripsikan hasil analisis pengamatan aktivitas guru, aktivitas siswa, respon siswa, dan hasil belajar. Jenis penelitian kualitatif menurut Prabowo dan Heriyanto (2013:5) adalah penelitian yang berhubungan dengan ide persepsi, pendapat, dan kepercayaan orang yang akan diteliti dan kesemuanya tidak dapat diukur dengan angka.

Subjek Penelitian adalah Siswa kelas V SDN Gadung Driyorejo Gresik tahun ajaran 2019/2020 dengan jumlah 29 siswa dalam satu kelas, siswa laki-laki yang berjumlah

Pengumpulan data menggunakan teknik observasi, tes dan angket.

Teknik analisis data meliputi analisis data aktivitas guru, analisis data aktivitas siswa, respon siswa dan tes hasil belajar.

\section{Analisa Data Aktivitas Guru}

$$
\text { Presentase aktivitas guru }=\frac{A}{B} \times 100 \%
$$

Keterangan :

A : Rata-rata frekuensi setiapkategori

$\mathrm{B}$ : Nilai tertinggi dari penilaian kategori

Kualifikasi hasil perhitungan data aktivitas guru sesuai dengan tabel berikut:

Tabel 1. Kriteria Aktivitas Guru Berdasarkan Skor Standar

\begin{tabular}{|l|l|}
\hline $\begin{array}{l}\text { Rentang } \\
\text { Nilai }\end{array}$ & Kategori \\
\hline $81 \%-100 \%$ & Baik Sekali \\
\hline
\end{tabular}

\begin{tabular}{|c|l|}
\hline $61 \%-80 \%$ & Baik \\
\hline $41 \%-60 \%$ & Cukup \\
\hline $21 \%-40 \%$ & Kurangbaik \\
\hline$<20 \%$ & Kurang Sekali \\
\hline
\end{tabular}

(Aqib, dkk, 2010:41)

\section{Analisa Data Aktivitas Siswa}

$$
\text { Pesentase }(\%)=\frac{\text { Skor perolehan }}{\text { Skor Maksimal }} \times 100
$$

Keterangan :

$\mathrm{P}$ : Presentase aktivitas siswa

$\mathrm{F}$ : banyakanya aktivitas siswa yang muncul

$\mathrm{N}$ : jumlah aktivitas keseluruhan

Kriteria tingkat keberhasilan aktivitas siswa yang bersifat kualitatif sebagai berikut:

Tabel 2. Kriteria Presentse Aktivitas Siswa

\begin{tabular}{|l|l|}
\hline $\begin{array}{l}\text { Rentang } \\
\text { Nilai }\end{array}$ & Kategori \\
\hline $81-100 \%$ & Sangat Aktif \\
\hline $61-80 \%$ & Aktif \\
\hline $41-60 \%$ & Cukup Aktif \\
\hline $21-40 \%$ & Kurang Aktif \\
\hline $0-20 \%$ & $\begin{array}{l}\text { Sangat kurang } \\
\text { baik }\end{array}$ \\
\hline
\end{tabular}

(Arkianto, 2007:44)

\section{Analisa Data Respon Siswa}

Tabel 3. Kriteria Skala Linkert

\begin{tabular}{|l|l|}
\hline Kriteria & Nilai Skor \\
\hline Sangat setuju & 4 \\
\hline Setuju & 3 \\
\hline Tidak setuju & 2 \\
\hline $\begin{array}{l}\text { Sangat tidak } \\
\text { setuju }\end{array}$ & 1 \\
\hline
\end{tabular}

(Rasyid dkk. 2016:94)

Rumus yang digunakan dalam perhitungan untuk mendapatkan presentase adalah sebagai berikut:

$$
\text { Pesentase }(\%)=\frac{\Sigma f}{N} \times 100
$$

Keterangan:

$\mathrm{P}$ : Pesentase respon siswa

$\sum \mathrm{f}:$ Jumlah penelitian jawaban

$\mathrm{N}$ : Banyaknya subjek 
Analisa Data Hasil Belajar

1) Menghitung presentase klsikal

Untuk menghitung presentase

ketuntasan belajar siswa secara klasikal digunakan rumus sebagai berikut :

$$
\mathrm{P}=\frac{f}{N} \times 100 \%
$$

Tabel 4.Hasil Belajar

\begin{tabular}{|l|l|}
\hline $\begin{array}{l}\text { Rentang } \\
\text { Nilai }\end{array}$ & Kategori \\
\hline $81-100 \%$ & Sangat Tuntas \\
\hline $61-80 \%$ & Tuntas \\
\hline $41-60 \%$ & Cukup Tuntas \\
\hline $21-40 \%$ & $\begin{array}{l}\text { Kurang } \\
\text { Tuntas }\end{array}$ \\
\hline $0-20 \%$ & $\begin{array}{l}\text { Sangat } \\
\text { Kurang } \\
\text { Tuntas }\end{array}$ \\
\hline
\end{tabular}

\section{HASIL DAN PEMBAHASAN}

\section{Hasil Observasi Aktivitas Guru}

Berdasarkan data hasil penelitian yang dilakukan oleh obsever dan teman sejawat dapat diperoleh data sebagai berikut:

Tabel 5. Hasil Observasi Aktivitas Guru

\begin{tabular}{|l|l|l|}
\hline & Jumlah & 73 \\
\hline & Rata-Rata & 4,29 \\
\hline & Nilai Rata-Rata & 2,52 \\
\hline & $\begin{array}{l}\% \quad \text { Klasikal } \\
\text { Aktivitas Guru }\end{array}$ & $82,3 \%$ \\
\hline & $\begin{array}{l}\text { Kategori } \\
\text { Penilaian }\end{array}$ & Sangat baik \\
\hline
\end{tabular}

Berdasarkan tabel 5 hasil Observasi Aktivitas guru pada saat pertemuan awal hingga akhir proses belajar mengajar dapat dilihat dari 17 Aspek yang diperoleh presentase Aktivitas guru $82,3 \%$ termasuk kategori sangat baik.

\section{Hasil Observasi Aktivitas Siswa}

Berdasarkan hasil pengamatan aktivitas siswa yang di lakukan oleh teman sejawat selama proses kegiatan pembelajaran dengan melibatkan 29 siswa, diperoleh data sebagai berikut:
Tabel 6. Hasil Observasi Aktivitas Siswa

\begin{tabular}{|l|l|l|}
\hline & Jumlah & 73 \\
\hline & Rata-Rata & 4,29 \\
\hline & Nilai Rata-Rata & 2,52 \\
\hline $\begin{array}{l}\text { \% Klasikal } \\
\text { Aktivitas Siswa }\end{array}$ & $82,3 \%$ \\
\hline $\begin{array}{l}\text { Kategori } \\
\text { Penilaian }\end{array}$ & Sangat baik \\
\hline
\end{tabular}

Berdasarkan Tabel 6 di atas dapat disimpulkan bahwa aktivitas siswa dalam pelaksanaan kegiatan pembelajaran IPA menggunakan model pembelajaran kooperatif tipe Jigsaw Sangat Aktif.

\section{Hasil Respon Siswa}

Dari kuesioner respon siswa menunjukan seberapa besar respon peserta didik terhadap pembelajaran kooperatif tipe JIGSAW. Setelah selesai pembelajaran peneliti mengumpulkan data dengan metode angket. Peneliti menyebarkan angket kepada 5 responden, siswa memberikan tanggapan dari 10 pernyataan. Setelah melakukan penyebaran angket peneliti mendapatkan hasil dan tanggapan responden dalam bentuk tabel di bawah ini.

Tabel 7. Hasil Respon Siswa

\begin{tabular}{|l|l|l|}
\hline Pilihan & Frekuensi & Presentase \\
\hline Sangat Setuju & 108 & $62 \%$ \\
\hline Setuju & 63 & $36 \%$ \\
\hline Tidak setuju & 0 & $0 \%$ \\
\hline $\begin{array}{l}\text { Sangat tidak } \\
\text { setuju }\end{array}$ & 1 & $5 \%$ \\
\hline Jumlah & $\mathbf{1 7 2}$ & $\mathbf{1 0 0 \%}$ \\
\hline
\end{tabular}

Berdasarkan Tabel 7 Presentase siswa dapat diketahui bahwa banyak siswa kelas V SDN Gadung Driyorejo Gresik sangat setuju dengan penerapan model cara menghitung. Pembelajaran kooperatif tipe JIGSAW pada materi perubahan wujud benda dengan presentase $62 \%$.

\section{Hasil Belajar}

Daftar Nilai Ketuntasan hasil belajar peserta didik dengan menggunakan model pembelajaran Kooperatif tipe Jigsaw bisa dilihat pada tabel dibawah ini: 

Tabel 8. Hasil Nilai Hasil Belajar

\begin{tabular}{|c|c|c|c|c|c|}
\hline \multirow{2}{*}{$\begin{array}{l}\text { NO } \\
.\end{array}$} & \multirow{2}{*}{$\begin{array}{l}N A M A \\
S I S W A\end{array}$} & \multirow[b]{2}{*}{ NILAI } & \multirow[b]{2}{*}{$K K M$} & \multicolumn{2}{|c|}{ KETERANGAN } \\
\hline & & & & $\begin{array}{c}T U N T A \\
S\end{array}$ & $\begin{array}{c}\text { TIDAK } \\
\text { TUNTAS }\end{array}$ \\
\hline 1. & A.N.R & 80 & 75 & $\sqrt{ }$ & \\
\hline 2. & A.D.A & 85 & 75 & $\sqrt{ }$ & \\
\hline \multirow[t]{2}{*}{3.} & $A$ & 80 & 75 & $\sqrt{ }$ & \\
\hline & A.N.R.A & 85 & 75 & $\sqrt{ }$ & \\
\hline 5. & A.Y.A.S & 80 & 75 & $\sqrt{ }$ & \\
\hline 6. & A.N.A & 60 & 75 & & $\sqrt{ }$ \\
\hline 7. & G.B.S & 90 & 75 & $\sqrt{ }$ & \\
\hline 8. & J. W & 90 & 75 & $\sqrt{ }$ & \\
\hline 9. & J.A & 95 & 75 & $\sqrt{ }$ & \\
\hline 10. & K.R.W & 90 & 75 & $\sqrt{ }$ & \\
\hline 11. & L.C.P & 100 & 75 & $\sqrt{ }$ & \\
\hline 12. & M.N.R & 85 & 75 & $\sqrt{ }$ & \\
\hline 13. & M.A.R & 90 & 75 & $\sqrt{ }$ & \\
\hline 14. & $\begin{array}{l}M . \\
D . A . W . K\end{array}$ & 100 & 75 & $\sqrt{ }$ & \\
\hline 15. & H.I.A.R & 75 & 75 & . & $\sqrt{ }$ \\
\hline 16. & M.R.G & 95 & 75 & $\sqrt{ }$ & \\
\hline 17. & N.A.P & 90 & 75 & $\sqrt{ }$ & \\
\hline \multirow[t]{2}{*}{18.} & O.A.B & 80 & 75 & $\sqrt{ }$ & \\
\hline & R.I.S & 85 & 75 & $\sqrt{ }$ & \\
\hline 20. & R.F.A & 90 & 75 & $\sqrt{ }$ & \\
\hline 21. & R.D.A & 80 & 75 & $\sqrt{ }$ & \\
\hline 22. & R.S.N & 90 & 75 & $\sqrt{ }$ & \\
\hline 23. & R.A.S & 95 & 75 & $\sqrt{ }$ & \\
\hline 24. & R.D.F & 95 & 75 & $\sqrt{ }$ & \\
\hline 25. & $S . O$ & 95 & 75 & $\sqrt{ }$ & \\
\hline 26. & V.Y & 70 & 75 & & $\sqrt{ }$ \\
\hline 27. & Y.D.A & 100 & 75 & $\sqrt{ }$ & \\
\hline 28. & $S . T$ & 100 & 75 & $\sqrt{ }$ & \\
\hline 29. & A.C.P & 80 & 75 & $\sqrt{ }$ & \\
\hline \multicolumn{2}{|c|}{ JUMLAH } & \multicolumn{4}{|c|}{2,530} \\
\hline \multicolumn{2}{|c|}{$R A T A-R A T A$} & \multicolumn{4}{|c|}{87,24} \\
\hline
\end{tabular}

Berdasarkan tabel 8 menunjukkan bahwa ketuntasan hasil belajar peserta didik Secara klasikal presentase sebesar 87,24\% dari 29 peserta didik sehingga hasil belajar dapat dinyatakan tuntas.

\section{KESIMPULAN}

Dari data di atas dapat disimpulkan bahwa (1) Aktivitas Guru dengan menggunakan model pembelajaran kooperatif tipe JIGSAW pada proses pembelajaran IPA materi perubahan wujud benda masuk dalam kategori Baik Sekali. (2) Aktivitas Siswa dengan menggunakan model pembelajaran kooperatif tipe JIGSAW pada mata pelajaran IPA materi perubahan wujud benda SDN Gadung Driyorejo Gresik masuk dalam kategori Sangat Aktif .(3) Respon Siswa dinyatakan positif setelah melakukan pembelajaran pada mata pelajaran IPA dengan menerapkan model pembelajaran kooperatif tipe JIGSAW. Dengan demikian respon siswa dalam pembelajaran termasuk kategori Positif. (4) Hasil Belajar dengan menggunkan model pembelajaran kooperatif tipe JIGSAW pada materi perubahan wujud benda di kelas $\mathrm{V}$ masuk dalam kategori Sangat Tuntas. Hal tersebut ditunjukan pada hasil peserta didik tuntas secara klasikal.

\section{DAFTAR RUJUKAN}

Aris, S. (2016). Model Pembelajaran Inofatif. Yogyakarta: Ar-Ruzz Media. 
Astiti, D. S., \& Widiana, W. (2017). Penerapan Metode Pembelajaran Jigsaw Sebagai Upaya Meningkatkan Hasil Belajar IPA Pada Siswa Kelas IV SD. Ilmiah Sekolah Dasar, 1.(1). Retrieved Januari 05, 2019, from https://ejournal.undiksha.ac.id/index.ph $\mathrm{p} / \mathrm{JISD} /$ article/view/10125

Faiza, W. N. (2014). Penerapan Model Pembelajaran Kooperatif Tipe Jigsaw Tema Lingkungan Untuk Meningkatkan Hasil Belajar Siswa Kelas Ii SDN Bulusidokare. JPGSD, 02.(02).Retrieved Januari 05， 2019, from

https://jurnalmahasiswa.unesa.ac.id/ind ex.php/jurnal-penelitianpgsd/article/view/10661

Isjoni. (2009). Cooperatif Learning Efektivitas Pembelajaran Kelompok. bandung: Alfabeta.

Komara, E. (2014). Belajar Dan Pembelajaran Interaktif. Bandung: PT. Refika Aditama.

Nugroho, D. R., \& Rachman, A. (2013). Penerapan Model Pembelajaran Kooperatif Tipe (Team Games Tournament) TGT Terhadap Motivasi Siswa Mengikuti Pembelajaran Bola Voli Dikelas X SMAN ! Panggul Kabupaten Trenggalek. 01.(01).Retrieved Desember, 08, 2018, from

http://jurnalmahasiswa.unesa.ac.id/inde x.php/jurnal-pendidikanjasmani/article/download/2820/5733

Nurkholis. (2013). Pendidikan Dalam Upaya Memajukan Teknologi. Kependidikan, 1.(1).Retriefed Desember ， 08, 2019,fromhttp://ejournal.iainpurwokert o.ac.id/index.php/jurnalkependidikan/ar ticle/download/530/473/

Pratiwi, D. E. (2017). mastery learning dalam gaya belajar model KOLP materi menulis cerpen bagi siswa kelas VI Sekolah Dasar. INOVASI, 32.

Prabowo, a., \& M.IM, H. S. (2013). 1Analisis Pemanfaatan Buku Elektronik ( E-Book ) Oleh Pemustaka Di Perpustakaan Sma Negeri 1 Semarang. Ilmu Perpustakaan, 2.(2). Retriefed Februari, 25, 2019, From http://ejournal.iainpurwokerto.ac.id/ind ex.php/jurnalkependidikan/article/down load/530/473/

Suprijono, A. (2009). Cooperatif Learning. Yogyakarta: Pustaka Belajar. 